\begin{tabular}{|c|c|}
\hline & $\begin{array}{c}\text { International Journal of Current Research in } \\
\text { Biosciences and Plant Biology } \\
\text { BXCELLENT } \\
\text { PUBLISHERS }\end{array}$ \\
Volume $4 \bullet$ Number 4 (April-2017) $\bullet$ ISSN: 2349-8080 (Online) \\
Journal homepage: www.ijcrbp.com
\end{tabular}

\title{
Shrinking Role of Silviculture in Tree Improvement in India
}

\author{
Manmohan J.R. Dobriyal ${ }^{1}$, Arvind Bijalwan ${ }^{2}$ and Tarun Kumar Thakur ${ }^{3}$
}

${ }^{I}$ College of Forestry, Navsari Agricultural University, Navsari, Gujarat, India

${ }^{2}$ Indian Institute of Forest Management (IIFM) Bhopal, M.P., India

${ }^{3}$ Indira Gandhi National Tribal University, Amarkantak, M.P., India

*Corresponding author.

\section{Abstract}

Silviculture deals with art and science of growing trees while tree breeding for genetic improvement of trees but tree Improvement is a harmonious alliance of tree breeding and Silviculture. This sacred union in last two decades has been skewed towards tree breeding and biotechnology while silviculture approach has been completely marginalized. There is a need for precision silviculture to assist national tree improvement program with the judicious use of tree breeding and biotechnology along with pest and disease control for developing complete tree farming technology for foresters, farmers and industries. The silvicultural practices of many of LKTS (Lesser Known Tree Species) and agroforestry trees are yet to be developed after their selection and propagation is standardized to promote indigenous species. There is also need to develop linkages with all stakeholders for better feedback and refinement of strategy in tree improvement. In this brief review, the shrinking role of silviculture in tree improvement with reference to the situation prevailing in India is discussed along with the key reasons for its shrinkage.
\end{abstract}

\section{Article Info}

Accepted: 17 March 2017

Available Online: 06 April 2017

Keywords

Biotechnology

Lesser known tree species

Silviculture

Tree improvement

\section{Introduction}

Silviculture deals with art and science of growing trees leading to establishment, development, care and production of stand of timber. Tree Improvement is a harmonious alliance of tree breeding and Silviculture, however, this union has skewed towards tree breeding and biotechnology almost in last two decades and silviculture approach has completely marginalized. The status of tree improvement in India is not vibrant and vivid in terms of selection of improved tree, clones and varietal development from the plantations or forests. The short rotation forestry around the globe has emerged to fulfill the requirement of industrial wood with joint efforts of industries and forest scientists. The Forest Survey of India (FSI) report, 2013 says that out of $76 \%$ natural forest in India about $63 \%$ is of seed origin while only $6 \%$ area is under plantation forests. Further, only 7.6\% forest area has big timbers, 53\% has recruiters (seedlings) and poles and $3.39 \%$ area under agroforestry (FSI, 2013). The productivity of Indian forests is 0.5$0.7 \mathrm{~m}^{3} / \mathrm{ha} / \mathrm{yr}$ (MoEF, 2006; Saravanan et al., 2015) which is far below than the world average of $3 \mathrm{~m}^{3} / \mathrm{ha} / \mathrm{yr}$ (FAO, 2009; FSI, 2015).

Though efforts made by Institute of Forest Genetics and Tree Breeding (ICFRE-IFGTB), Coimbatore, India are praise worthy in tree improvement but their impact 
to provide superior and elite planting material for plantation is still limited. However, initiative for ENVIS centre on Forest Genetic Resources and Tree improvement since 2014 by IFGTB provided a platform to share and disseminate the information of forest genetic resources of India is a welcome step (http://envis.nic.in/ifgtb/about_envis_ifgtb.html\#).

India has a rich repository of Forest Genetic resources (FGR) particularly tree resources of ecological and economical significance. Role of trees in socioeconomic development and contribution to the forest based industries prompted need to focus on improving the productivity of forest plantations through tree improvement, involving breeding, biotechnology and silviculture. The information on these valuable resources as well as the improvement efforts lies scattered in various statistics and research reports of forest departments, agricultural universities and woodbased industries which are to be pooled in single database and coordinated network projects need to be formed.

\section{Recent approaches}

Recently, FSI (2015) reported 24.16\% (21.34\% + $2.82 \%$ ) as forest and tree cover in India. The figures gives a clear indication that neither recorded forest nor Trees outside forest has much improved in coverage as well as in the productivity. The definition of fast growing species in commercial forestry around the globe to change the wood volume is $>50 \mathrm{~m}^{3}$ per ha per year but in India we still repeating $10 \mathrm{~m}^{3}$ while natural forest productivity is below $1 \mathrm{~m}^{3}$. There has been lot of tree breeding, biotechnological and clonal work done in different laboratories but silviculture of those selected species/ clones / improved material has not worked out resulting low returns. One cannot think about perfect tree improvement without silvicultural practices. The strategy of tree improvement needs to be relook in holistic way and development of field trials based on tree improvement principles.

The silviculture of developed clones or varieties has to be worked for their life period or at least half of rotation to confirm the results and further improvement. The laboratory and nursery results seldom trusted for perennial long gestation trees. We feel the tree breeding work has to be followed by precision silviculture practices to make a complete tree improvement package of a species especially in timber species. Many times in industrial wood like paper and pulp, plywood the focus is on biomass only but in case of timber wood quality parameters are equally important along with physical and mechanical properties of wood. These wood quality parameters are response of silvicultural practices over the period of time in a species.

The precision silviculture is not only required for short rotation forestry but also in long rotation trees to achieve higher quality and quantity of wood yield. Although advancement is done in clonal forestry and development of quality planting material for the certain tree species like Eucalyptus, Populus, Casuarina, Leucaena, Ailanthus, Bamboo, Teak, Anthocephalus, Mahogany, Melia, etc. has done but still many species are on the way to attain this phase. Further, the silvicultural practices of many of LKTS (Lesser Known Tree Species) are yet to be developed after their selection and propagation is standardized to promote indigenous species. There is also need to develop linkages with all stakeholders for better feedback and refinement of strategy in tree improvement.

The plant protection aspects are also limited to nursery and not at plantation level which needs to look for enhance productivity along with irrigation/ fertilizer if possible. Intensive plantation requires time bound precise silvicultural practices to get a high productivity in short period. It is important to be noticed that in future tree improvement programme will redefine the role of precision silviculture in tree improvement and bring it from margin to main frame of research plan to achieve the increasing results. It is worth mentioning that in India neither forest department nor private foresters adopting the intensive silviculture practices in plantation unlike in clonal propagation stage which resulting low production. In agroforestry, there is option for intensive cultivation of trees within the crops as farmers fertilize and irrigate the crop and same inputs are utilized by trees. The development of proper silvicultural schedule for agroforestry trees along with crops will certainly increases the total productivity in agriculture.

There is a need for precision silviculture to assist national tree improvement program rather focusing only biotechnological tools for plants propagation. The judicious use of tree breeding, biotechnology and silviculture with pest and disease control is need for developing complete tree farming technology for foresters, farmers and industries. 


\section{Conflict of interest statement}

Authors declare that they have no conflict of interest.

\section{References}

FAO, 2009. Indian Forestry Outlook Study by The Ministry of Environment and Forests Government of India. Food and Agricultural Organization of the United Nations Regional Office for Asia and the Pacific, Bangkok. 72p.

FSI, 2013. India State of Forest Report, 2013, FSI, Dehradun, India.
FSI, 2015. India State of Forest Report, 2015, FSI, Dehradun, India.

MoEF, 2006, Compendium of Environmental Statistics. Ministry of Environment and Forests, New Delhi, India.

Saravanan, V., Parthiban, K.T., Thirunirai, R., Kumar., Vennila, P. S., Umesh Kanna, S., 2014. Comparative study of wood physical and mechanical properties of Melia dubia with Tectona grandis at different age gradation. Res. J. Recent Sci. 2014(3), 256-263.

http://envis.nic.in/ifgtb/about_envis_ifgtb.html\#

\section{How to cite this article:}

Dobriyal, M. J. R., Bijalwan, A., Thakur, T. K., 2017. Shrinking role of silviculture in tree improvement in India. Int. J. Curr. Res. Biosci. Plant Biol. 4(4), 104-106. doi: https://doi.org/10.20546/ijcrbp.2017.404.015 